\title{
Kualitas Benih Berdasarkan Warna Kulit dan Bagian Buah, serta Kualitas Bibit Srikaya dengan Pemberian PGPR dan $\mathrm{CaCO}_{3}$
}

\author{
Seed Quality Based on Exocarp Color and Fruit Part, and Quality of \\ Sugar Apple Seedling on PGPR and $\mathrm{CaCO}_{3}$ Applications
}

\author{
Riski Meliya Ningsih ${ }^{1}$, Eny Widajati ${ }^{2 *}$, dan Endah Retno Palupi ${ }^{2}$ \\ 'Program Studi Ilmu dan Teknologi Benih, Sekolah Pascasarjan, Institut Pertanian Bogor \\ ${ }^{2}$ Departemen Agronomi dan Hortikultura, Fakultas Pertanian, Institut Pertanian Bogor \\ (IPB University), Jl. Meranti, Kampus IPB Darmaga, Bogor 16680, Indonesia
}

Diterima 8 Juli 2021/Disetujui 27 Agustus 2021

\begin{abstract}
Srikaya's high quality seeds are needed to support development of srikaya. This study aimed to determine the level of maturity and position of the seeds in the fruit in order to get quality seeds and get the best treatment to improve seedling performance through the use of rhizobacteria and $\mathrm{CaCO}_{3}$. The first experiment used a two-factor completely randomized design (CRD), with the first factor of the color of the exocarp of the fruit and the second factor of the position of the seed in the fruit. The second experiment used CRD with rhizobacteria, $\mathrm{CaCO}_{3}$, and a combination of both as a single factor. The first count time was observed for germination at 36 days after planting $(D A P)$ and the final count was at 56 DAP. The best seed quality was obtained from the yellow exocarp color based on seed dry weight, germination, vigor index, normal germination dry weight, and seed growth speed. The highest seed growth vigor was obtained from fruit with yellow exocarp color from the tip and base of the fruit. $\mathrm{CaCO}_{3}$ treatment affected root elongation, leaf width, stem diameter, and leaflength. Application $\mathrm{CaCO}_{3}$ gives the best effect on seedling growth followed by Pseudomonas + Actimomycetes $+\mathrm{CaCO}_{3}$ treatment.
\end{abstract}

Keywords: Annona squamosa, rootstock, final count, vigor index, rhizobacteria

\section{ABSTRAK}

Benih srikaya yang bermutu sangat diperlukan untuk mendukung pengembangan bibit tanaman srikaya. Penelitian ini bertujuan menentukan tingkat kemasakan dan posisi benih dalam buah yang tepat guna mendapatkan benih bermutu dan mendapatkan perlakuan terbaik untuk meningkatkan performa bibit melalui penggunaan rizobakteri dan $\mathrm{CaCO}_{3}$. Percobaan pertama menggunakan rancangan acak lengkap (RAL) dua faktor dengan faktor pertama adalah warna kulit buah dan faktor kedua adalah posisi benih dalam buah. Percobaan kedua menggunakan RAL dengan rizobakteri, CaCO ${ }_{3}$, dan kombinasi keduanya sebagai faktor tunggal. Waktu hitungan pertama pengamatan daya berkecambah pada 36 hari setelah tanam (HST) dan hitungan akhir pada 56 HST. Kualitas benih terbaik diperoleh dari warna kulit buah kuning berdasarkan bobot kering benih, daya berkecambah, indeks vigor, bobot kering kecambah normal, dan kecepatan tumbuh benih. Vigor tumbuh benih tertinggi diperoleh dari buah dengan warna kulit kuning dari bagian ujung dan pangkal buah. Perlakuan $\mathrm{CaCO}_{3}$ mempengaruhi pemanjangan akar, lebar daun, diameter batang, dan panjang daun. Aplikasi $\mathrm{CaCO}_{3}$ memberikan pengaruh terbaik terhadap pertumbuhan bibit diikuti dengan perlakuan Pseudomonas + Actimomycetes $+\mathrm{CaCO}_{3}$.

Kata kunci: Annona squamosa, batang bawah, hitungan akhir, indeks vigor rizobakteri

\section{PENDAHULUAN}

Tanaman srikaya (Annona squamosa Linn) umumnya diperbanyak secara vegetatif melalui okulasi dan sambung pucuk. Metode perbanyakan tersebut memerlukan batang bawah berkualitas baik ditandai oleh perakaran yang dalam, kuat, dan tahan terhadap patogen tanah. Batang bawah

\footnotetext{
* Penulis untuk korespondensi. e-mail: eny_widajati@apps.ipb. ac.id
}

yang berkualitas diperoleh dari bibit yang berasal dari benih, karena memiliki perakaran yang kuat, oleh karena itu diperlukan benih berkualitas. Penelitian tentang benih srikaya bermutu untuk sumber batang bawah masih sangat terbatas.

Kualitas benih dipengaruhi tingkat kemasakan benih dalam buah, yang secara visual dapat ditunjukkan dengan perubahan warna kulit buah. Tingkat kemasakan benih kemiri sunan dapat diukur berdasarkan total karotenoid dalam benih, semakin tua umur benih konsentrasi senyawa 
tersebut semakin meningkat (Tresniawati et al., 2014). Benih jeruk Satsuma Mandarin (Citrus unshiu Marc.) mengalami peningkatan jumlah karotenid dalam proses pemasakan buah (Kato et al., 2004). Pada tanaman kakao, masak fisiologis benih dicapai pada saat bobot kering benih maksimum yaitu 135-150 hari setelah anthesis (Baharudin et al., 2011).

Berdasarkan penelitian Sahroni et al. (2018) benih kakao hibrida yang telah masak fisiologis mampu berkecambah mencapai $81 \%$ dan benih yang berasal dari bagian pangkal dan tengah buah memiliki pertumbuhan terbaik. Pada benih nangka Komala et al. (2014) menyatakan bahwa bagian pangkal menghasilkan bibit yang paling baik, kemudian diikuti benih bagian tengah dan benih bagian ujung.

Upaya untuk meningkatkan kualitas bibit untuk batang bawah juga dapat dicapai melalui penggunaan plant growth promoting rhizobacteria (PGPR). Rizobakteri dari genus Pseudomonas dan Actinomycetes pada saat ini banyak diaplikasikan sebagai PGPR (Agustiansyah et al., 2013; Asih et al., 2017). Pemanfaatan rizobakteri diharapkan dapat memicu perkembangan perakaran menjadi lebih baik dan lebih sehat karena akar yang sehat sangat diperlukan untuk batang bawah sekaligus melindungi bibit dari patogen pada fase pembibitan. Penggunaan $\mathrm{CaCO}_{3}$ untuk meningkatkan $\mathrm{pH}$ tanah sehingga akar dapat berkembang dengan baik. Tujuan penelitian ini adalah mendapatkan benih srikaya bermutu tinggi sebagai sumber batang bawah, serta mendapatkan perlakuan $\mathrm{CaCO}_{3}$, rizobakteria atau kombinasi yang tepat untuk meningkatkan mutu bibit srikaya.

\section{BAHAN DAN METODE}

\section{Percobaan I. Mutu Benih Berdasarkan Warna Kulit Buah dan Posisi Benih dalam Buah Srikaya}

Penelitian dilaksanakan pada bulan Oktober Desember 2019 di Laboratorium Ilmu dan Teknologi Benih. Percobaan menggunakan Rancangan Acak Lengkap (RAL) dua faktor. Faktor pertama adalah warna kulit buah dan faktor kedua adalah posisi benih pada buah. Faktor pertama terdiri atas tiga taraf yaitu warna kulit hijau, hijau kekuningan, dan kuning. Faktor kedua terdiri atas tiga taraf posisi benih yaitu pangkal, tengah, dan ujung. Seluruhnya terdapat 9 kombinasi perlakuan dengan 4 kali ulangan.

Sebelum ditanam benih diskarifikasi menggunakan gunting kuku untuk mempermudah imbibisi benih. Benih ditanam dalam bak plastik ukuran $38 \mathrm{~cm}$ x $30 \mathrm{~cm}$ x $12 \mathrm{~cm}$ dengan media tanam pasir. Pengamatan perkecambahan benih dilakukan selama 60 hari mengikuti prosedur dari Paramita (2017)

Pengamatan meliputi daya berkecambah, indeks vigor, potensi tumbuh maksimum, kecepatan tumbuh, bobot kering benih, bobot kering kecambah normal. Penentuan first count pada uji daya berkecambah dilakukan dengan menentukan persentase kecambah normal harian tertinggi dan final count dilakukan dengan penentuan kecambah normal kumulatif tertinggi.
Kecambah normal pertama muncul pada 26 hari setelah tanam (HST). Pengamatan hitungan pertama (first count) dalam pengujian daya berkecambah ditetapkan berdasarkan jumlah kecambah normal harian tertinggi pada 36 HST. Pengamatan hitungan akhir (final count) ditetapkan berdasarkan jumlah kecambah normal kumulatif tertinggi pada 50 HST (Gambar 1).

\section{Percobaan II. Aplikasi Rizobakteri dan $\mathrm{CaCO}_{3}$ terhadap Pertumbuhan Bibit Srikaya}

Penelitian dilaksanakan pada bulan Januari sampai dengan April 2020 di lahan percobaan Cikabayan dan Laboratorium Kesehatan Benih, Institut Pertanian Bogor, Jawa Barat. Benih yang digunakan berdasarkan hasil Percobaan I yaitu benih yang berasal dari buah dengan warna kulit kuning yang memiliki viabilitas dan vigor yang tinggi . Rancangan yang digunakan adalah RAL satu faktor yaitu 8 perlakuan aplikasi yaitu tanpa aplikasi, Pseudomonas, Actinomycetes, $\mathrm{CaCO}_{3}$, Pseudomonas + Actinomycetes, Pseudomonas $+\mathrm{CaCO}_{3}$, Actinomycetes $+\mathrm{CaCO}_{3}$, dan Pseudomonas + Actinomycetes $+\mathrm{CaCO}_{3}$. Seluruh perlakuan diulang 3 kali sehingga didapatkan 24 satuan percobaan.

Rizobakteri yang digunakan terdiri atas Pseudomonas isolat P30 asal isolat koleksi Laboratorium Bakteriologi Departemen Proteksi Tanaman Institut Pertanian Bogor (Ratdiana 2011) dan Actinomycetes isolat AB2 asal isolat tanah perakaran bambu (Himmah 2012). Peremajaan isolat rizobakteri dilakukan dengan cara merekultur masing-masing isolat pada media NA lalu diinkubasi pada suhu ruang selama 48 jam. Kepadatan sel rata-rata dihitung menggunakan spectrofotometer Shimadzu UV-1280 menghasilkan \pm 1.49 x $10^{9} \mathrm{cfu} \mathrm{mL}^{-1}$ untuk Pseudomonas dan $\pm 2.69 \times 10^{9} \mathrm{cfu} \mathrm{mL}^{-1}$ untuk Actinomycetes. Selanjutnya dilakukan uji antagonis antar isolat untuk mengetahui kompatibilitas rizobakteri dalam medium NA dengan metode gores, prosedur pengujian tersebut mengikuti Ratdiana (2011).

Media tanam yang digunakan campuran tanah dengan pupuk kandang kotoran sapi 1:1 dalam polybag ukuran 8 $\mathrm{cm}$ x $9 \mathrm{~cm}$ menggunakan $1 \mathrm{~kg}$ media per polybag. Pada perlakuan media dicampur $\mathrm{CaCO}_{3}$ diberikan pada satu minggu sebelum tanam sebanyak 6 g per polybag. Aplikasi rizobakteri dilakukan dengan merendam benih dalam suspensi masing-masing perlakuan rizobakteri selama 24 jam (Khalimi dan Wirya 2010) dengan konsentrasi \pm 3.94 x $10^{9}$ cfu $\mathrm{mL}^{-1}$. Benih dengan perlakuan kontrol dan $\mathrm{CaCO}_{3}$ direndam dengan air.

Tanaman yang mendapat perlakuan rizobakteri disiram menggunakan masing-masing larutan suspensi rizobakteri dengan konsentrasi \pm 5.75 x $10^{9} \mathrm{cfu} \mathrm{mL}^{-1}$ pada bagian perakaran bibit pada umur 60 hari setelah tanam (HST) dengan volume larutan $100 \mathrm{~mL}$ per polybag. Pengamatan bibit setiap minggu meliputi tinggi tanaman, diameter batang, jumlah daun, panjang daun, lebar daun, dan luas segitiga stamina. Pengamatan terakhir pada bibit umur 90 HST meliputi tinggi tanaman, diameter batang, jumlah daun, panjang daun, lebar daun, luas segitiga stamina, bobot akar, bobot basah tajuk, dan panjang akar. 


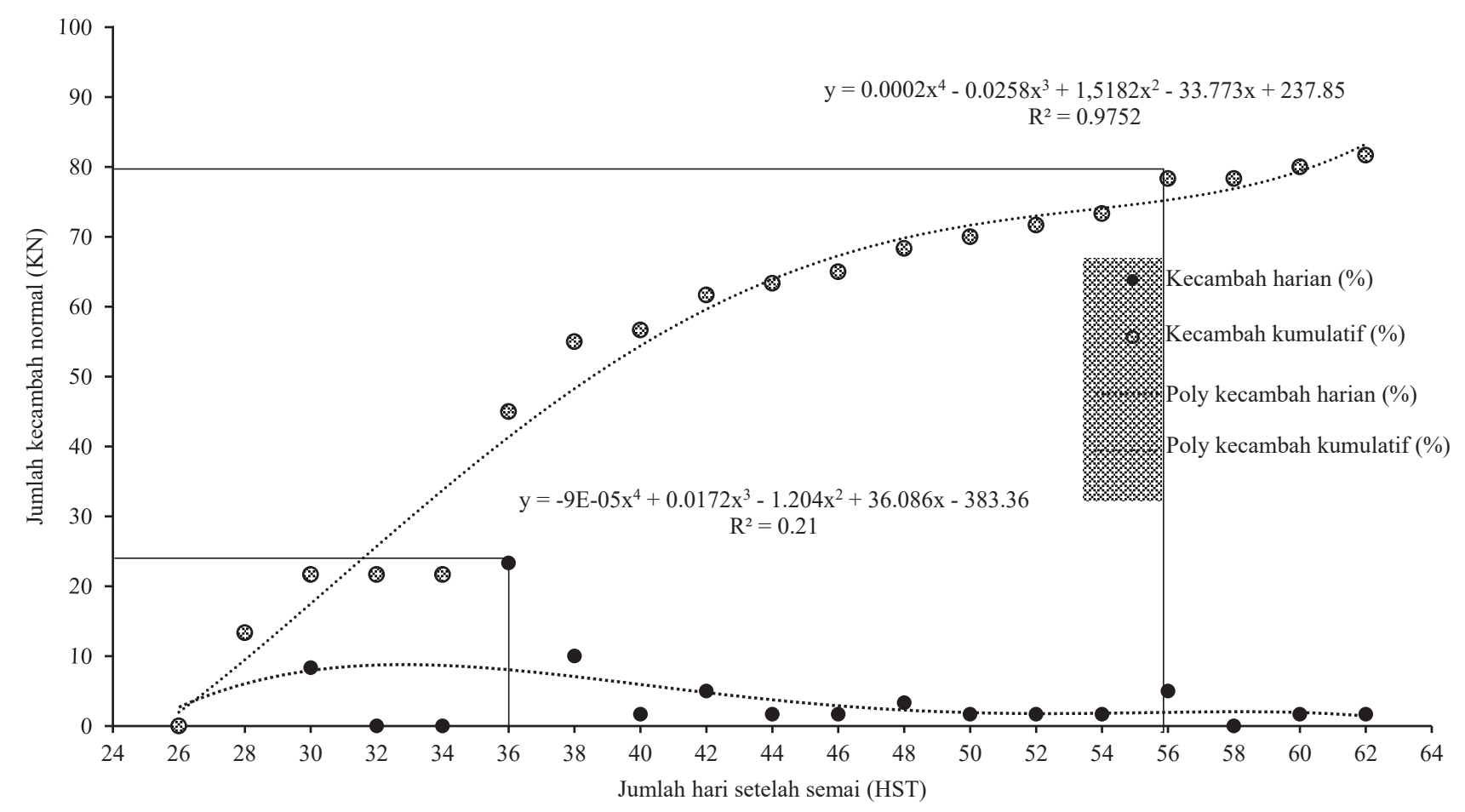

Gambar 1. Kurva penentuan hitungan perkecambahan benih srikaya dengan warna kulit buah kuning

Data dianalisis menggunakan IBM SPSS Statistics 22 Analysis of varians taraf $\alpha 5 \%$. Apabila perlakuan memberikan pengaruh nyata maka dilanjutkan dengan uji Duncan's Multiple Range Test (DMRT) taraf $\alpha$ 5\% untuk melihat perbedaan antar perlakuan.

\section{HASIL DAN PEMBAHASAN}

\section{Percobaan I. Mutu Benih Berdasarkan Warna Kulit Buah} dan Posisi Benih dalam Buah Srikaya

Benih yang dihasilkan dari tiga tingkat kemasakan yang diuji tidak semua berhasil tumbuh menjadi kecambah normal. Kecambah normal srikaya dapat dilihat pada pola perkecambahan benih srikaya yang mana kecambah telah terbentuk dengan sempurna dengan kriteria kotiledon berkembang berwarna hijau berbentuk bulat panjang dengan ujung lancip (Gambar 2). Sebagian benih menghasilkan kecambah abnormal dengan kriteria kerusakkan pada akar kecambah terangkat ke atas permukaan tanah, batang tidak tegak lurus, dan kotiledon mengalami pembusukan atau patah (Gambar 3). Tipe perkecambahan benih srikaya adalah fanerokotilar. Tipe perkecambahan fanerokotilar adalah kecambah yang kotiledonnya muncul, kotiledon tersebut terangkat ke atas permukaan media tumbuh (epigeal) sehingga dapat melakukan proses asimilasi.

Benih srikaya mencapai masak fisiologis ketika kulit buah berwarna kuning yang ditunjukkan dengan peubah bobot kering benih maksimum, daya berkecambah tertinggi, bobot kering kecambah normal, indeks vigor, dan kecepatan tumbuh benih yang nyata paling tinggi (Tabel 1). Benih yang berasal dari bagian ujung dan pangkal buah dengan warna kulit kuning memiliki potensi tumbuh yang sama dan nyata lebih tinggi dibandingkan benih dari kombinasi buah warna hijau dan hijau kekuningan pada posisi yang sama (Tabel 2).

Berdasarkan hasil penelitian ini bahwa benih asal buah dengan warna kulit kuning memiliki daya berkecambah nyata lebih tinggi dibandingkan benih asal buah dengan warna kulit hijau dan hijau kekuningan. Hal ini membuktikan

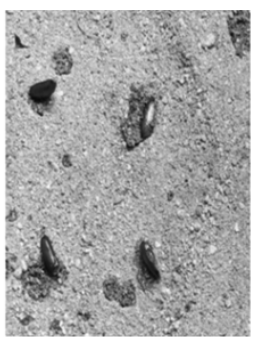

0 HSS

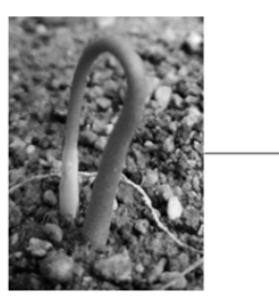

32 HSS

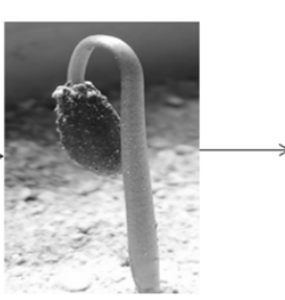

33 HSS

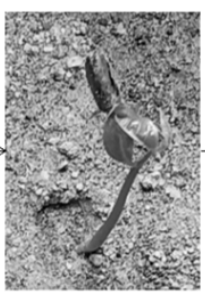

35 HSS



36 HSS

Gambar 2. Pola perkecambahan normal benih srikaya 

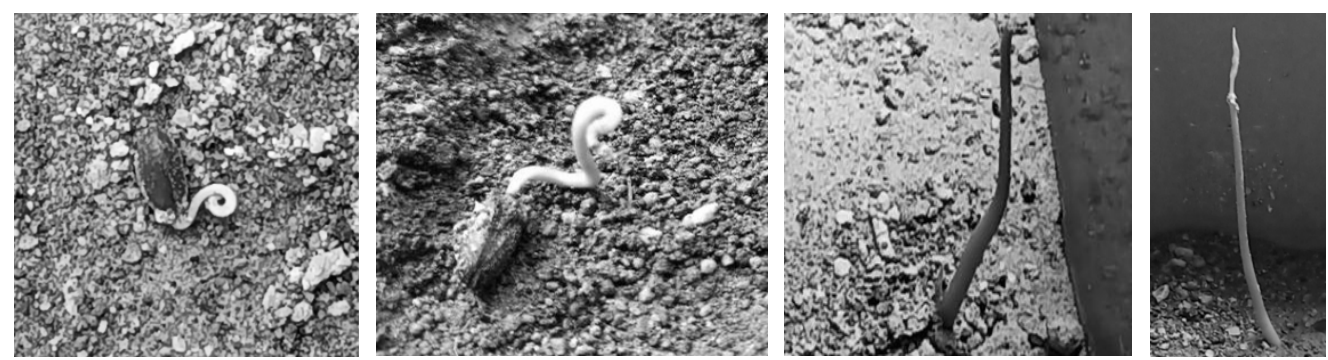

Gambar 3. Kecambah abnormal benih srikaya

bahwa daya berkecambah benih yang sudah mencapai masak fisiologis mampu merepresentasikan kemampuan benih untuk tumbuh dan berkembang dalam kondisi yang optimum.

Bobot kering kecambah normal benih asal buah dengan warna kulit kuning nyata lebih tinggi dibandingkan dua perlakuan lainnya. Hal ini juga sejalan dengan bobot kering benih, yang mana hal ini mengindikasikan bahwa bobot benih memiliki pengaruh terhadap kualitas tegakan bibit yang akan terbentuk. Peningkatan bobot benih menunjukkan adanya pertumbuhan akibat akumulasi bahan organik ke dalam struktur penyusun benih. Seiring pemasakan buah dan benih terjadi adanya peningkatan bahan organik yang disimpan dalam jaringan benih, terutama bagian endosperm. Pada benih tanaman aren menurut Widyawati et al. (2010) pertambahan bobot segar dan kering benih terjadi akibat akumulasi makromolekul ke dalam jaringan benih, antara lain berupa pati, gula, protein, lemak, lignin, serta tanin. Benih dengan vigor tinggi akan lebih cepat tumbuh dibandingkan dengan vigor rendah (Rori et al., 2018)

Benih yang berasal dari kulit buah kuning dengan posisi benih di bagian pangkal dan ujung buah menunjukkan potensi tumbuh maksimum benih terbaik (Tabel 2). Adanya perbedaan dalam potensi tumbuh benih antar bagian buah diduga karena proses pemasakan buah. Berdasarkan pengamatan di lapangan, proses pemasakan benih srikaya dimulai dari bagian pangkal buah kemudian bertahap ke bagian tengah dan berakhir pada ujung buah. Pangkal buah adalah bagian terdekat dengan tangkai buah. Tabel 1 dan Tabel 2 menunjukkan bahwa benih yang berasal dari buah dengan warna kulit hijau kekuningan tidak direkomendasikan untuk digunakan sebagai bahan tanam. Dengan demikian, benih yang direkomendasikan berasal dari buah berwarna kuning pada bagian ujung dan pangkal buah.

\section{Percobaan II. Aplikasi rizobakteri dan $\mathrm{CaCO}_{3}$ terhadap Pertumbuhan Bibit Srikaya}

Pemberian rizobakteri dan $\mathrm{CaCO}_{3}$ tidak berpengaruh nyata terhadap pertumbuhan bibit srikaya pada pengamatan mingguan kecuali pada peubah jumlah daun di minggu ke-8 setelah tanam (Tabel 3). Perlakuan Pseudomonas dan Pseudomonas + Actinomycetes nyata meningkatkan jumlah daun bibit srikaya dibandingkan perlakuan kontrol.

Tabel 1. Mutu benih srikaya berdasarkan warna kulit buah

\begin{tabular}{lccccc}
\hline Warna kulit buah & BKB $(\mathrm{g})$ & DB $(\%)$ & IV $(\%)$ & Kct $(\% /$ etmal $)$ & BKKN $(\mathrm{g})$ \\
\hline Hijau & $0.116(-0.94) \mathrm{a}$ & $68.33(54.32) \mathrm{b}$ & $45.00(40.58) \mathrm{b}$ & $4.30(0.61) \mathrm{b}$ & $0.11(0.78) \mathrm{b}$ \\
Hijau kekuningan & $0.088(-1.06) \mathrm{b}$ & $25.00(26.07) \mathrm{c}$ & $15.00(17.51) \mathrm{c}$ & $2.01(0.24) \mathrm{c}$ & $0.07(0.75) \mathrm{c}$ \\
Kuning & $0.120(0.92) \mathrm{a}$ & $71.67(59.1) \mathrm{a}$ & $48.33(43.94) \mathrm{a}$ & $5.50(0.73) \mathrm{a}$ & $0.14(0.80) \mathrm{a}$ \\
\hline
\end{tabular}

Keterangan: Angka pada kolom yang sama yang diikuti huruf yang sama tidak berbeda nyata berdasarkan DMRT $\alpha=5 \%$. Data di dalam tanda kurung adalah nilai transformasi, sedangkan nilai rata-rata menggunakan data asli. BKB = bobot kering benih per butir, DB = daya berkecambah dan IV = indeks vigor menggunakan transformasi akar $\arcsin (\mathrm{x}), \mathrm{Kct}=$ kecepatan tumbuh menggunakan transformasi logaritma, dan BKKN = bobot kering kecambah normal menggunakan transformasi akar (x)

Tabel 2. Potensi tumbuh benih srikaya (\%) berdasarkan warna kulit buah dan posisi benih dalam buah

\begin{tabular}{lccc}
\hline \multirow{2}{*}{ Warna kulit buah } & \multicolumn{3}{c}{ Posisi benih pada buah } \\
\cline { 2 - 4 } & Pangkal & Tengah & Ujung \\
\hline Hijau & $60.00(7.53) \mathrm{bc}$ & $95.00(9.76) \mathrm{a}$ & $55.00(7.37) \mathrm{c}$ \\
Hijau kekuningan & $55.00(7.37) \mathrm{c}$ & $65.00(7.99) \mathrm{bc}$ & $35.00(5.64) \mathrm{d}$ \\
Kuning & $95.00(9.76) \mathrm{a}$ & $70.00(8.34) \mathrm{b}$ & $90.00(9.50) \mathrm{a}$ \\
\hline
\end{tabular}

Keterangan: Angka pada kolom dan baris yang diikuti huruf yang sama tidak berbeda nyata berdasarkan DMRT $\alpha=5 \%$. Data di dalam tanda kurung menggunakan hasil transformasi akar (x), sedangkan nilai rata-rata menggunakan data asli 
Tabel 3. Pertambahan jumlah daun bibit srikaya pada 8 MST sebagai respon terhadap perlakuan rizobakteri

\begin{tabular}{lc}
\hline Perlakuan & $\begin{array}{c}\text { Jumlah daun } \\
\text { (helai) }\end{array}$ \\
\hline Kontrol & $2.8 \mathrm{c}$ \\
Pseudomonas & $4.9 \mathrm{a}$ \\
Actinomycetes & $3.6 \mathrm{~b}$ \\
$\mathrm{CaCO}_{3}$ & $4.4 \mathrm{~b}$ \\
Pseudomonas + Actinomycetes & $4.5 \mathrm{a}$ \\
Pseudomonas $+\mathrm{CaCO}_{3}$ & $4.1 \mathrm{~b}$ \\
Actinomycetes $+\mathrm{CaCO}_{3}$ & $4.3 \mathrm{~b}$ \\
Pseudomonas + Actinomycetes $+\mathrm{CaCO}_{3}$ & $4.3 \mathrm{~b}$ \\
\hline
\end{tabular}

Keterangan: Angka pada kolom yang sama yang diikuti huruf yang sama tidak berbeda nyata berdasarkan DMRT $\alpha 5 \%$

Berdasarkan hasil penelitian Agustiansyah et al. (2013) pada benih tanaman padi yang diberi perlakuan Pseudomonas diminuta A6 yang diperlakukan secara tunggal maupun dicampur dengan Bacillus subtilis 5B ataupun yang dikombinasikan dengan matriconditioning cukup efektif meningkatkan tinggi tanaman dan jumlah daun.

Pada penelitian ini, perlakuan $\mathrm{CaCO}_{3}$, Pseudomonas + Actinomycetes, Pseudomonas $+\mathrm{CaCO}_{3}$, dan Pseudomonas + Actinomycetes $+\mathrm{CaCO}_{3}$ memberikan pengaruh nyata meningkatkan lebar daun, diameter batang, panjang daun, dan panjang akar bibit srikaya (Tabel 4). Respon pertumbuhan bibit srikaya berdasarkan perlakuan dilihat dari peubah pengamatan lebar daun tanaman terbaik ditunjukan oleh pemberian $\mathrm{CaCO}_{3}$, dan tidak berbeda nyata dengan perlakuan $\mathrm{CaCO}_{3}$ yang dikombinasikan dengan aplikasi rizobakteri Pseudomonas + Actinomycetes $+\mathrm{CaCO}_{3}$. Panjang daun terbaik ditunjukan oleh perlakuan Pseudomonas +
$\mathrm{CaCO}_{3}, \mathrm{CaCO}_{3}$, dan Pseudomonas + Actinomycetes + $\mathrm{CacO}_{3}$. Sedangkan berdasarkan peubah diameter batang terbaik ditunjukan oleh perlakuan $\mathrm{CaCO}_{3}$, Pseudomonas + Actinomycetes, dan Pseudomonas $+\mathrm{CaCO}_{3}$.

Perlakuan $\mathrm{CaCO}_{3}$ menunjukkan respon pertumbuhan akar terbaik berdasarkan peubah panjang akar diikuti perlakuan Pseudomonas + Actinomycetes $+\mathrm{CaCO}_{3}$. Pemberian $\mathrm{CaCO}_{3}$ berperan penting dalam menjaga stabilitas membran sel, penyerapan ion, metabolisme meristem dan pembelahan sel, serta berkontribusi terhadap pertumbuhan dan perkembangan tanaman (Kolodziejek dan Patykowski, 2015). Hasil penelitian Asih et al. (2017) menunjukan bahwa kelompok rizobakteri Azotobacter dan Actinomycetes mampu memproduksi hormon pertumbuhan, menambat $\mathrm{N}$, siderofor pengkelat besi, melarutkan $\mathrm{P}$, memproduksi antibiotik, dan enzim-enzim ekstraselular yang melindungi tanaman dari patogen.

Pemberian perlakuan Pseudomonas + Actinomycetes dan Pseudomonas sp. $+\mathrm{CaCO}_{3}$ memiliki bobot akar tertinggi sebesar $3.11 \mathrm{~g}$ dan $2.97 \mathrm{~g}$ (Tabel 4). Perlakuan rizobakteri cenderung lebih mempengaruhi pertumbuhan perakaran tanaman jika dibandingkan dengan pertumbuhan bagian atas tanaman. Pada tanaman cabai rawit, Pseudomonas sp. mampu mempengaruhi kelarutan unsur $\mathrm{P}$ yang terikat menjadi tersedia guna untuk perangsangan proses pembungaan secara maksimal (Al Habib et al., 2017), dengan kemampuan melarutkan hingga 50\% dari total kebutuhan P tanaman. Lebih lanjut dikemukakan bahwa kemampuan mikroba sebagai pelarut posfat disebabkan oleh adanya kemampuan melepaskan asam organik yang dapat memecah ikatan logam sehingga fosfor yang terikat menjadi larut dan tersedia. Rizobakteri jenis Actinomycetes memiliki aktivitas antibakteri dengan mekanisme menghambat pertumbuhan rizobakteri antagonis melalui interaksi elektrostatik sehingga mempunyai antimikroba yang luas terhadap berbagai patogen (Masda, 2018).

Tabel 4. Pengaruh pertumbuhan bibit srikaya terhadap respon pemberian rizobakteri dan $\mathrm{CaCO}_{3}$ pada umur 12 MST

\begin{tabular}{lccccc}
\hline Perlakuan & LD $(\mathrm{cm})$ & PD $(\mathrm{cm})$ & DB $(\mathrm{mm})$ & PA $(\mathrm{cm})$ & $\mathrm{BA}(\mathrm{g})$ \\
\hline Kontrol & $4.29 \mathrm{~b}$ & $13.25 \mathrm{c}$ & $0.28 \mathrm{~b}$ & $13.46 \mathrm{c}$ & $1.32 \mathrm{c}$ \\
Pseudomonas & $4.59 \mathrm{~b}$ & $14.73 \mathrm{~b}$ & $0.31 \mathrm{ab}$ & $13.70 \mathrm{c}$ & $1.77 \mathrm{c}$ \\
Actinomycetes & $4.32 \mathrm{~b}$ & $13.46 \mathrm{c}$ & $0.30 \mathrm{ab}$ & $12.39 \mathrm{~d}$ & $1.34 \mathrm{c}$ \\
$\mathrm{CaCO}_{3}$ & $5.50 \mathrm{a}$ & $16.56 \mathrm{a}$ & $0.37 \mathrm{a}$ & $18.22 \mathrm{a}$ & $1.97 \mathrm{bc}$ \\
Pseudomonas + Actinomycetes & $4.75 \mathrm{~b}$ & $13.36 \mathrm{c}$ & $0.37 \mathrm{a}$ & $15.50 \mathrm{ab}$ & $3.11 \mathrm{a}$ \\
Pseudomonas $+\mathrm{CaCO}_{3}$ & $4.92 \mathrm{ab}$ & $16.67 \mathrm{a}$ & $0.34 \mathrm{a}$ & $16.50 \mathrm{ab}$ & $2.97 \mathrm{a}$ \\
Actinomycetes $+\mathrm{CaCO}_{3}$ & $4.94 \mathrm{ab}$ & $14.42 \mathrm{~b}$ & $0.26 \mathrm{~b}$ & $15.19 \mathrm{~b}$ & $2.44 \mathrm{~b}$ \\
Pseudomonas + Actinomycetes $+\mathrm{CaCO}_{3}$ & $5.17 \mathrm{a}$ & $16.27 \mathrm{a}$ & $0.31 \mathrm{ab}$ & $17.87 \mathrm{a}$ & $2.26 \mathrm{~b}$ \\
\hline
\end{tabular}

Keterangan: $\mathrm{LD}=$ lebar daun; $\mathrm{PD}=$ panjang daun; $\mathrm{DB}=$ diameter batang; $\mathrm{PA}=$ panjang akar; $\mathrm{BA}=$ bobot akar. Angka pada kolom yang sama yang diikuti huruf yang sama tidak berbeda nyata berdasarkan DMRT $\alpha=5 \%$

\section{KESIMPULAN}

Periode masak benih srikaya terbaik diperoleh dari buah dengan kriteria kulit berwarna kuning berdasarkan peubah bobot kering benih per butir, daya berkecambah, indeks vigor, bobot kering kecambah normal per kecambah, dan kecepatan tumbuh benih. Benih dari buah berwarna kuning pada posisi ujung dan pangkal memiliki potensi 
tumbuh benih terbaik. Aplikasi $\mathrm{CaCO}_{3}$ memberikan pengaruh terbaik terhadap pertumbuhan bibit diikuti dengan perlakuan Pseudomonas + Actimomycetes $+\mathrm{CaCO}_{3}$.

\section{DAFTAR PUSTAKA}

Agustiansyah, S. Ilyas, Sudarsono, M. Machmud. 2013. Perlakuan benih dengan agen hayati dan pemupukan P untuk meningkatkan pertumbuhan tanaman, hasil, dan mutu benih padi. J. Agron. Indonesia 41:98-104.

Al Habib, I.M., D.S. Sukamto, L. Maharani. 2017. Potensi mikroba tanah untuk meningkatkan pertumbuhan dan hasil tanaman cabai rawit (Capsicum frutescens L.). J. Folium. 1:28-36.

Asih, P.R., M. Surahman, Giyanto. 2017. Isolasi rizobakteri dan pengaruh aplikasinya dengan pupuk N-P terhadap mutu benih dan pertumbuhan bibit tetua betina jagung. J. Agron. Indonesia 45:255-262.

Baharudin, M.R. Suhartanto, S. Ilyas, A. Purwantara. 2011. Perubahan biologis dan fisiologis sebagai indikator masak benih kakao hibrida. J. Littri. 17:41-50.

Himmah, N.I.F. 2012. Seleksi dan identifikasi Actinomycetes sebagai agens hayati untuk pengendalian penyakit kresek yang disebabkan oleh Xanthomonas oryzae pv. oryzae pada padi. Skripsi. Institut Pertanian Bogor. Bogor.

Kato, M., Y. Ikoma, H. Matsumoto, M. Sugiura, H. Hyodo, M. Yano. 2004. Accumulation of carotenoids and expression of carotenoids biosynthetic genes during germination in citrus fruit. Plant Physiol. 134:824837.

Khalimi, K., G.N.A.S. Wirya. 2010. Pemanfaatan plant growth promoting rhizobacteria untuk biostimulants dan bioprotectants. Ecotrophic. 4:131-135.

Kolodziejek, J., J. Patykowski. 2015. The effect of temperature, light and calcium carbonate on seed germination and radicle growth of the polycarpic perennial Galium cracoviense (Rubiaceae), a narrow endemic species from Southern Poland. Acta Biol. Cracoviensia. 57:70-81.

Komala, S., S. Purwanti, S. Trisnowati. 2014. Pengaruh letak biji dalam buah dan tiga macam pupuk organik terhadap daya tumbuh dan pertumbuhan bibit nangka (Artocarpus integra L). Vegetalika 3:98-106.

Masda, N.R. 2018. Potensi metabolit sekunder isolat Actinomycetes SM-2 dari rizosfer Andrographis paniculate sebagai penghasil senyawa anti bakteri. Skripsi. Universitas Hasanuddin. Makassar.

Paramita, K.E. 2017. Optimasi pengujian daya berkecambah dan faktor yang mempengaruhi viabilitas dan vigor benih kelor (Moringa oleifera Lam.) dalam penyimpanan. Skripsi. Institut Pertanian Bogor. Bogor.

Ratdiana. 2011. Penapisan dan karakterisasi bakteri antagonis yang berpotensi sebagai agens hayati untuk pengendalian penyakit karat putih pada krisan. Tesis. Sekolah Pascasarjana Institut Pertanian Bogor. Bogor.

Rori, H.F., H.L. Rampe, M. Rumondor. 2018. Viabilitas dan vigor biji sirsak (Annona muricata L.) setelah aplikasi kalium nitrat $\left(\mathrm{KNO}_{3}\right)$. J. Ilmiah Sains 18:80-84.

Sahroni, M., T.T. Handayani, Yulianti, Zulkifli. 2018. Pengaruh perendaman dan letak posisi benih dalam buah terhadap perkecambahan dan pertumbuhan kecambah benih kakao (Theobroma cacao L.). J. Bio Eksperimen dan Keanekaragaman Hayati 5:27-36.

Tresniawati, C., E. Murniati, E. Widajati. 2014. Perubahan fisik, fisiologi dan biokimia selama pemasakan benih dan studi rekalsitransi benih kemiri sunan. J. Agron. Indonesia 42:74-79.

Widyawati, N., Tohari, P. Yudono, I. Soemardi. 2010. Biokimiawi dan daya berkecambah benih aren. Agric. 22:28-35. 